\title{
Estimating internal $P$ loading in a deep water reservoir of northern China using three different methods
}

\author{
Lihuan Qin ${ }^{1,2}$ • Qinghui Zeng ${ }^{1,2}$ - Wangshou Zhang ${ }^{1,2}$ - Xuyong Li $^{1}$ • \\ Alan D. Steinman ${ }^{3} \cdot$ Xinzhong Du ${ }^{4}$
}

Received: 13 November 2015 / Accepted: 5 June 2016 /Published online: 11 June 2016

(C) Springer-Verlag Berlin Heidelberg 2016

\begin{abstract}
Much attention had been paid to reducing external loading of nutrients to improve water quality, while internal loading from sediment, which has been largely neglected, is also an important source for water eutrophication. The internal load in deep lakes or reservoirs is not easy to be detected and be quantified. In this study, three different methods (mass balance method, Fick's law, and regression equation) were combined to calculate the gross or/and net $\mathrm{P}$ release from sediment using limited data. Our results indicated that (1) the methods of mass balance and regression equation give similar results of sediment $\mathrm{P}$ release rate, with values of 0.889 and $0.902 \mathrm{mg} \mathrm{m}^{2} \mathrm{~d}^{-1}$, respectively, while the result of Fick's law was much lower $\left(0.400 \mathrm{mg} \mathrm{m}^{2} \mathrm{~d}^{-1}\right)$; (2) Hot periods of sediment releasing were suggested to occur from March to April and from August to September, which correspond to periods of high risks of algae blooms. The remaining months of the year were shown as net nutrient retention; (3)
\end{abstract}

Responsible editor: Hailong Wang

Electronic supplementary material The online version of this article (doi:10.1007/s11356-016-7035-0) contains supplementary material, which is available to authorized users.

Xuyong Li

xyli@rcees.ac.cn

1 State Key Laboratory of Urban and Regional Ecology, Research Center for Eco-Environmental Sciences, Chinese Academy of Sciences, Shuangqing Road 18, Beijing 100085, China

2 University of Chinese Academy of Sciences, Beijing 100049, China

3 Annis Water Resources Institute, Grand Valley State University, Muskegon, MI 49441, USA

4 Department of Civil and Environmental Engineering, Jackson State University, Jackson, MS 39056, USA for the whole region, Baihedam and Chaohekuqu were identified as zones with a higher possibility to release $\mathrm{P}$ from sediment. (4) P loading to the Miyun Reservoir was greater in the inflow than in the outflow, suggesting a portion of the inflow P load was retained in the water or sediment; hence, release of sediment $\mathrm{P}$ may continue to be a major source of phosphorus in the future.

Keywords Internal P loading $\cdot$ Fick's law $\cdot$ Mass balance method $\cdot$ Regression method

\section{Introduction}

Despite scientific advances that have been made over the past few decades, eutrophication of lakes or reservoirs remains a worldwide concern (Søndergaard et al. 2012). Phosphorus (P) availability is a key factor that affects the water quality. Many studies have shown that large loads of $\mathrm{P}$ can lead to algal blooms, which is one of the main causes of water quality deterioration (Anderson et al. 2002; Conley et al. 2009), such as declines in water transparency and loss of biodiversity (Søndergaard et al. 2003; Steinman et al. 2004; Lewis et al. 2007; Yang et al. 2013).

On a large scale, efforts to restore water quality were usually focused on reducing external $\mathrm{P}$ loading and have achieved promising results (Penn et al. 2000; Jeppesen et al. 2007). However, in some circumstances, internal P loading from sediment is sometimes sufficient to maintain a eutrophic status even the external sources of nutrients have been reduced or eliminated (Haggard et al. 2005; Lewis et al. 2007). For example, during the 1970 s to the 1990 s, more than $60 \%$ of external $\mathrm{P}$ inputs in Loch Leven has been reduced, while the results of monitoring has shown that the water quality is slowly improving (Spears et al. 2012). It also happened in Lake 
Ringsjön, even a drastic reduction in the external nutrient loading, in few years, the water quality did not respond quickly (Granéli 1999). Furthermore, an analysis covers 35 lakes to examine the lake's responses to reduced nutrient loading, and it revealed that both shallow and deep lakes typically used 1015 years to reach a new equilibrium between sediment and water column (Jeppesen et al. 2005). This was due to the reduction of $\mathrm{P}$ import which may be counterbalanced by the high internal loading from the sediment. In addition, previous studies also showed that internal P loading can play an important role in algal boom (Nürnberg 1985; Soranno et al. 1997; Smith et al. 2011). Soranno et al. (1997) suggested internal loading altered the nutrient ratio and boosted blue green algae. Orihel et al. (2013) showed that the release nutrient from sediment stimulated the blooms of toxigenic cyanobacteria. As a result, it can be found that internal $\mathrm{P}$ loading delays the lake recovery even after reducing the external input and very important in water eutrophication (Zhou et al. 2001; Nürnberg and LaZerte 2004; Søndergaard et al. 2012; Bertrand et al. 2015)

The role of sediment as sink of contaminants, such as nutrients, heavy metals, and some organic chemicals, has been studied for years and well documented (Cornwell et al. 2014). The process of the sediment act as sink was via burial, microbial denitrification, and assimilation by algae or macrophytes (Lehtoranta et al. 2009). However, sediment is also a source of the nutrient. Phosphorus can be released from sediment below the water-sediment interface $20 \mathrm{~cm}$ (Søndergaard et al. 2003). The internal P loading sometimes could be very high. In Lake Winnipeg, the internal phosphorus loading was almost the same with the external load (Nürnberg and LaZerte 2016). As a result, internal $\mathrm{P}$ loading should not be ignored.

Various methods can be used to assess internal P loading, such as in situ flux measurements, sediment core incubations, mass balance methods, regression equation related to sediment P content (Nürnberg 1988), and the methods based on Fick's law, most of which were widely adopted in the previous studies (Lavery et al. 2001; Bhadha et al. 2011; Koriyama et al. 2013). In situ flux chambers result in minimal disturbance to the sediment and overlying water (Burger et al. 2007), and to some extent, is the optimal way to get realworld results about the internal flux; However, it is also the most costly way to assess internal loading from sediment. In addition, to measure nutrient flux changes over time, the environment inside the chamber should be the same as that outside the chamber, which is the difficult part of the method. Similarly, sediment core incubation is also a direct way to measure the rate of sediment release (Steinman et al. 2009; Kowalczewska-Madura et al. 2010). As it is conducted in the laboratory, it is possible to control and manipulate specific factors. The drawback of the method is the limited number of sample sites, thereby introducing uncertainty when extrapolating to larger sediment areas. Fick's law method is an indirect way to measure flux based on nutrient gradient profiles, which reflect defined locations (Koriyama et al. 2013; Zhang et al. 2013). In contrast, the mass balance method calculates overall nutrient input and output of studied reservoir or lakes, allowing internal loading to be calculated (Kelderman et al. 2005). The regression equation is a worldwide equation based on the sediment $\mathrm{P}$ content data of 63 lakes around the world and widely used in many studies (Nürnberg 1988; Nürnberg et al. 2012; Nowlin et al. 2005). The advantage of the regress model is that it only contains two parameters, which are very useful for routine monitoring data. The limitation of this method, which was largely similar to the mass balance methodologies, is that the outputs are annual or seasonal based.

There are a substantial number of studies assessing internal $\mathrm{P}$ loading in shallow water bodies, river, lakes, or wetlands. But deep stratified lakes or reservoirs (mean depth $>5 \mathrm{~m}$ ) (Benndorf et al. 2002) have received less attention. This may be because internal loading is not easily observed in deep-water bodies, as increasing depth adds logistical challenges in experiment design and sampling.

The areas in Northern China are faced with serious water shortage (Du et al. 2014). Hence, it is extremely important to keep water quality clean and safe in Northern China. In this paper, we use different methods to assess the internal P loading of a deep stratified reservoir, the Miyun Reservoir (Li et al. 2014). As the largest surface water drinking resource in Beijing, permission to sample directly is limited. Therefore, we apply simple approaches (i.e., mass balance method, Fick's law, and the regression equation) to assess the internal $\mathrm{P}$ loading of the reservoir. Regression equation firstly provided a general evaluation about the internal $\mathrm{P}$ loading from the sediment. Then, a monthly mass balance method of $\mathrm{P}$ is used to calculate monthly internal P loading. Finally, Fick's law was used to examine the spatial distribution of internal $\mathrm{P}$ loading. These methods are simple, but are powerful and sufficient to address our purposes, since the methods were fully independent and results can complement each other. By combining these results, we are able to generate useful information for water quality management. Three questions were addressed in this study: (1) How much is the net or/and gross internal P loading of Miyun Reservoir? (2) Are there hot spots or moments in the reservoir? (3) What are the roles of inflows or outflows on internal P loading?

\section{Method}

\section{Study area}

The Miyun Reservoir $\left(40^{\circ} 29.0^{\prime}-40^{\circ} 30.5^{\prime} \mathrm{N}, 116^{\circ} 50.0^{\prime}-117^{\circ}\right.$ $3.5^{\prime} \mathrm{E}$ ) is located in the northern part of Beijing, China (Fig. 1). It was built in the $1960 \mathrm{~s}$, with a maximum water area of 


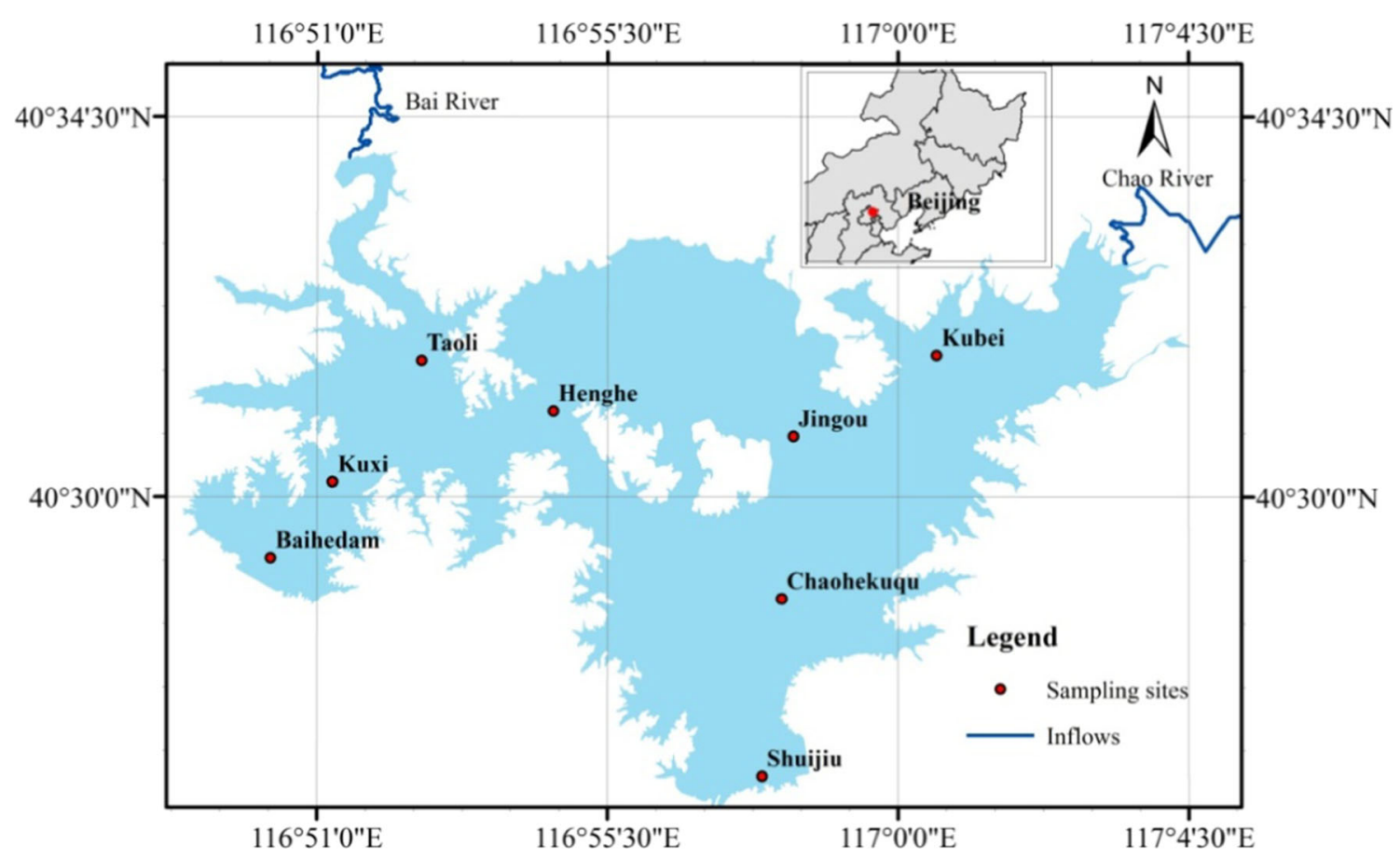

Fig. 1 Sampling sites of Miyun Reservoir

$188 \mathrm{~km}^{2}$ (Qin et al., 2016). Chao River and Bai River are the main rivers which flow into Miyun Reservoir. Chaohedam and Shuijiu are the main outlets. The catchment has a mostly warm temperate semi-humid monsoonal climate, and the annual average precipitation is close to $600 \mathrm{~mm}$, of which $80 \%$ is concentrated from July to August (Yang et al. 2015). The growing period is from April to October, and the reservoir is normally covered by ice from the middle of November to the end of March. Total phosphorus (TP) was relatively constant from 2002 to 2010 (Fig. 2), ranging from 0.013 to $0.022 \mathrm{mg} \mathrm{L}^{-1}$, with an average value at $0.0158 \mathrm{mg} \mathrm{L}^{-1}$ $(n=108)$; TN ranged from 0.580 to $1.880 \mathrm{mg} \mathrm{L}^{-1}$, with an

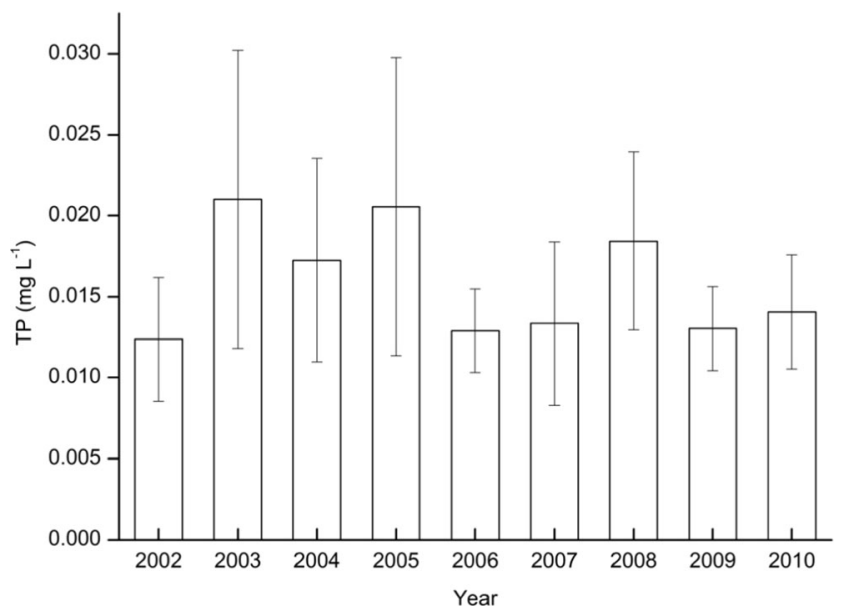

Fig. 2 Average TP change in the water column from year 2002 to year 2010. Error bars represent the standard deviation $(n=12)$ 8-year average value of $0.888 \mathrm{mg} \mathrm{L}^{-1}$. It is a P-limited reservoir (Zeng et al. 2015).

\section{Data sources and statistical analysis}

Surface sediments were sampled from eight stations in May 2012 and sediment cores were collected from eight sites in the reservoir using a gravity corer with plexiglas cores tubes (9-cm diameter, 60-cm length) (Fig. 1) in September 2014 (Autumn), April 2015 (Spring), and July 2015 (Summer). The sampled cores were 6 to $38 \mathrm{~cm}$ with a volume of overlying water. Each of the cores was divided into $0-1 \mathrm{~cm}$ sections. Pore water was extracted by centrifugation at $5000 \mathrm{rpm}$ for $10 \mathrm{~min}$ and then filtered through $0.45-\mu \mathrm{m}$ glass fibermembrane filters, and measured with the molybdenum blue method (Bertrand et al. 2015). Monthly inflows and outflows were obtained from the Miyun Reservoir management office (MRMO) for the period from year of 2002 to 2010. In addition, the concentration of total phosphorus (TP) in the inflows and outflows was obtained from MRMO. Precipitation and evaporation was obtained from the Miyun weather station.

The results are showed as mean \pm standard deviation. The significant of difference between means was analyzed by oneway ANOVA (Duncan's Test) and Kruskal-Wallis test with SPSS 16.0 for Windows.

\section{Methods description}

Figure 3 shows the framework of the combining of the three methods. The input data was very basic for monitoring, such 
Fig. 3 The framework of the combining three methods

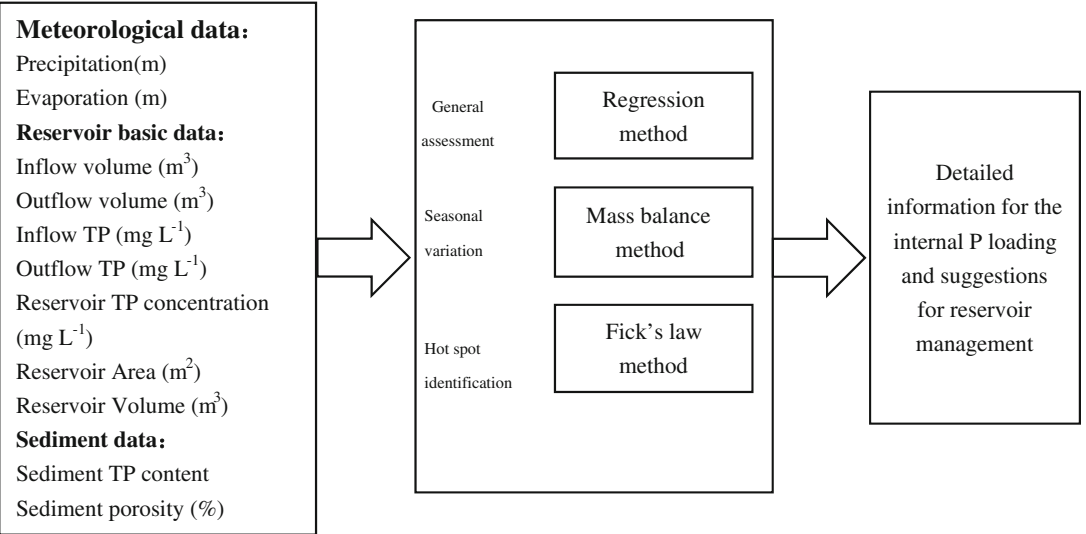

as precipitation and evaporation, inflow and outflow volume and its TP concentration; reservoir area, reservoir volume and TP concentration, sediment TP content and sediment porosity. The three methods were independent of each other, and each had a different focus. The regression method provided a general assessment of internal P loading in the whole area; the mass balance $\mathrm{P}$ method was able to obtain seasonal variation of internal P loading; and the Fick's law method, based on the gradient-diffusion theory of the sampling sites of sediment pore water with overlying water, identified hot spots. The framework that contained the three methods was designed to provide complementary results; from these combined results, a more detailed and rigorous analysis of internal $\mathrm{P}$ loading was derived, which in turn allowed more informed decision making in reservoir management.

\section{Regress method (gross loading)}

This method is based on the components of sediment and is a direct way to determine the gross internal loading (Nürnberg 2009). Regression method was a "worldwide" equation which was fit for stratified reservoir or lakes. As in stratified water bodies, some areas would turn into anaerobic zones in summer or winter, resulting in $\mathrm{P}$ release from the sediment to overlying water. The equation as follows:

$F=A F \times R R$

$A F=-36.2+50.1 \times \log (T P)+0.762 \times Z / A^{0.5}$

$R R=-5.59+0.079 \times T P_{s}$

For the area of the Miyun Reservoir, an empirical equation can be used as follows (Liu 2002):

$A=0.05 \times(G-96)^{2.0079}$

where $A F$ is the release area $\left(\mathrm{km}^{2}\right), R R$ is the release rate $\left(\mathrm{mg} \mathrm{m}{ }^{-2} \mathrm{~d}^{-1}\right), G$ is water level $(\mathrm{m}), A$ is reservoir area $\left(\mathrm{km}^{2}\right), Z$ is the average depth of the reservoir $(\mathrm{m})$, and $T P_{S}$ is the content of TP in the wet sediment $\left(\mu \mathrm{g} \mathrm{g}^{-1}\right)$.

\section{Mass balance method (net internal load)}

In order to quantify $\mathrm{P}$ net exchange in the sediment-water interface, a mass balance method was calculated (see supplementary material) (Kelderman et al. 2005; Pedusaar et al. 2010)

$F=T P_{\text {in }}-T P_{\text {out }}-\Delta \mathrm{TP}$

The average monthly inflows and outflows were based on daily flow data. TP concentration in inflows and outflows was based on monthly sampling data. The whole data used in Eq. 5 was from the year 2002 to 2010 .

For $\mathrm{P}$, retention can be calculated by the formula below (Koiv et al. 2011):

$R P=T P_{\text {in }}-T P_{\text {out }}$

where $F$ is net internal budget, $R P$ is the $\mathrm{P}$ retention amount by reservoir, $T P_{\text {in }}$ is external load, $T P_{\text {out }}$ is outflow loss, and $\triangle T P$ reflects the changes in water column TP storage over time. The units are $t$ year $^{-1}$.

\section{Flux calculations}

For deep lakes or reservoirs, wind is not the driving factor for sediment-water interface exchange; Rather, $P$ release by diffusive flux dominates the exchange process. Fick's law is based on the principle that concentration gradients trigger the exchange between two interfaces.

Diffusive flux of SRP (soluble reactive phosphorus) between water and sediment was calculated according to Fick's first law of diffusion (Bhadha et al. 2011; Graca et al. 2006)

$J=\phi \times D_{s} \times \frac{d c}{d z}$

Where $\phi$ is sediment porosity; $D_{s}$ is the bulk diffusion coefficient; $\frac{d c}{d z}$ is the concentration gradient at the sediment surface. 
$D_{s}=D^{s w} / \theta^{2}$

Where $D^{s w}$ molecular diffusion coefficient in seawater; $\theta$ is tortuosity

$\theta=\sqrt{1-\ln \left(\phi^{2}\right)}$

$\phi=W\left((100-W) d^{-1}+W\right)^{-1}$

Where $W(\%)$ is the sediment water content, $d$ is the average sediment bulk density $\left(2.6 \mathrm{~g} \mathrm{~cm}^{-3}\right)$.

\section{Results}

\section{Empirical formula}

To assess the amount of $\mathrm{P}$ released from sediment, we used the empirical formula (Nürnberg 1988). The average sediment $P$ concentration was $687.71 \pm 118.73 \mu \mathrm{g} \mathrm{g} \mathrm{g}^{-1}$ (Fig. 4). The sediment P content in Taoli, Kuxi, and Shuiju was 798.60, 810.00 , and $760.70 \mathrm{\mu g} \mathrm{g}^{-1}$ respectively. However, in Henghe, Chaohekuqu, and Baihedam, the TP concentration was $698.30,689.30$, and $697.00 \mu \mathrm{g} \mathrm{g}^{-1}$, respectively. In contrast, Jingou and Kubei had lower sediment $\mathrm{P}$ content, with about 445.5 and $600.60 \mu \mathrm{g} \mathrm{g}^{-1}$. The difference in sediment $\mathrm{P}$ among sites was statistically significant $(P<0.01)$. According to Eq. (3), RR is related to sediment TP content. Hence, sampling sites with higher TP content in the sediment would also release more $\mathrm{P}$. Thus, the order of the release rate from high to low was Kuxi $>$ Taoli $>$ Shuijiu $>$ Henghe $>$ Baihedam $>$ Chaohekuqu $>$ Jingou $>$ Kubei. In Fig. 2, the average TP of the water column in the Miyun Reservoir was $0.016 \mathrm{mg} \mathrm{L}^{-1}$.
So according to Eqs. (1)-(3), $F$ is $25.526 \mathrm{t}$ (for $Z=34.220 \mathrm{~m}$, $A=78.7024 \mathrm{~km}^{2}$ ). The average $\mathrm{P}$ release rate across the whole Miyun Reservoir was $0.889 \mathrm{mg} \mathrm{m}^{2} \mathrm{~d}^{-1}$.

\section{Mass balance method}

A monthly P mass balance was constructed to assess the net water-sediment exchange. This value is positive (representing a net sink) when $P$ retention exceeds release, and conversely, the quantity will be negative when $\mathrm{P}$ release exceeds $\mathrm{P}$ retention. The monthly $\mathrm{P}$ budgets from year 2002 to 2010 are shown in Fig. 5. The capacity of the sediment was variable with season and year. For example, in most years, there was a net retention of $\mathrm{P}$ from the sediments in February, July, and October-November, whereas sediments usually release $\mathrm{P}$ in other months (Fig. 5). The yearly release amount from sediment is presented in Table 1. From the year 2002 to 2010, 11.91 to $38.15 \mathrm{t} \mathrm{P} \mathrm{y}^{-1}$ of sediment $\mathrm{P}$ was released to the water (corresponding to 0.418 to $1.340 \mathrm{mg} \mathrm{m}^{2} \mathrm{~d}^{-1}$ ), with a multi-year average value at $25.69 \mathrm{t} \mathrm{y}^{-1}\left(0.902 \mathrm{mg} \mathrm{m}^{2} \mathrm{~d}^{-1}\right)$.

Correlations between inflow P loading, P retention, internal $\mathrm{P}$ loading, and mean annual precipitation were calculated by Pearson correlation. Inflow P load was positively related with both mean annual precipitation $(r=0.736, P=0.05)$ and $\mathrm{P}$ retention $(r=0.775$, $P=0.05)$. However, internal $\mathrm{P}$ loading had no positive relation with inflow $\mathrm{P}$ load or annual precipitation. In the year 2004 , the mean annual precipitation reached $681.8 \mathrm{~mm}$, so the inflow from upper rivers was the largest discharge during the study periods (2002-2010). As a result, the $\mathrm{P}$ retention load was also enlarged (Fig. 6).
Fig. 4 Mean TP content in the sediment of sampling sites in Miyun Reservoir $(n=3)$. Error bars represent the standard deviation. Significant differences between sampling sites are denoted by lowercase letters $(\alpha=0.05)$

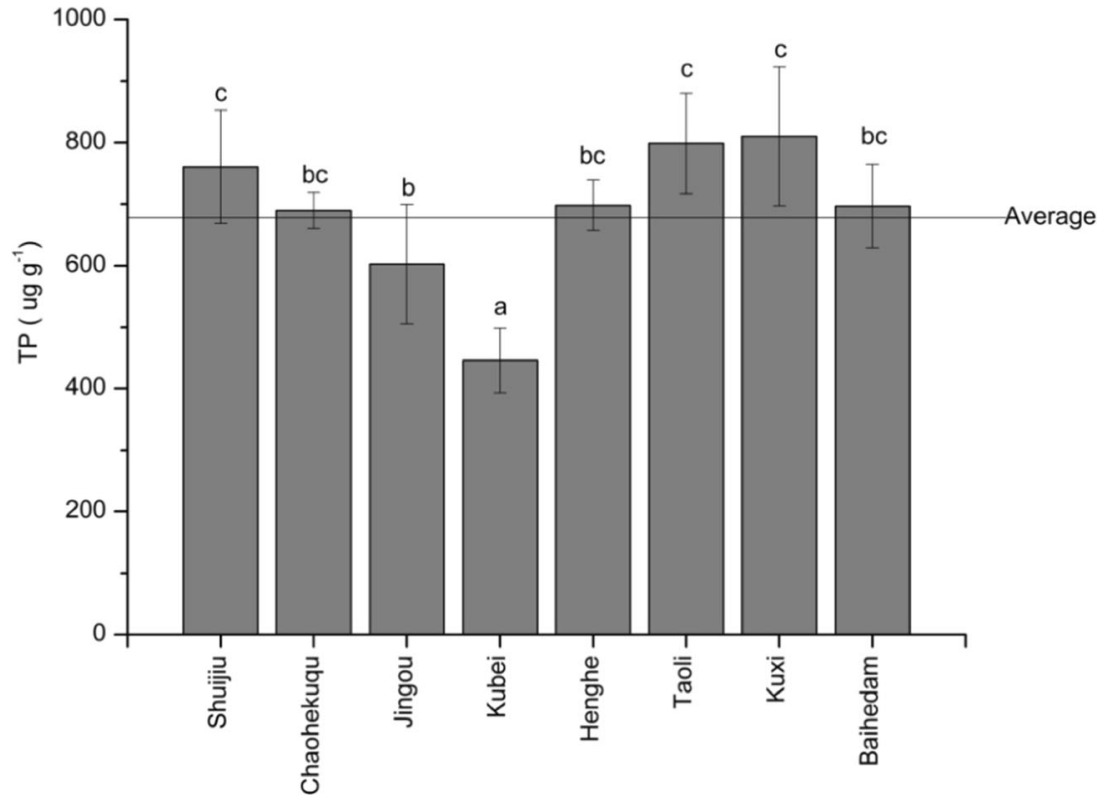




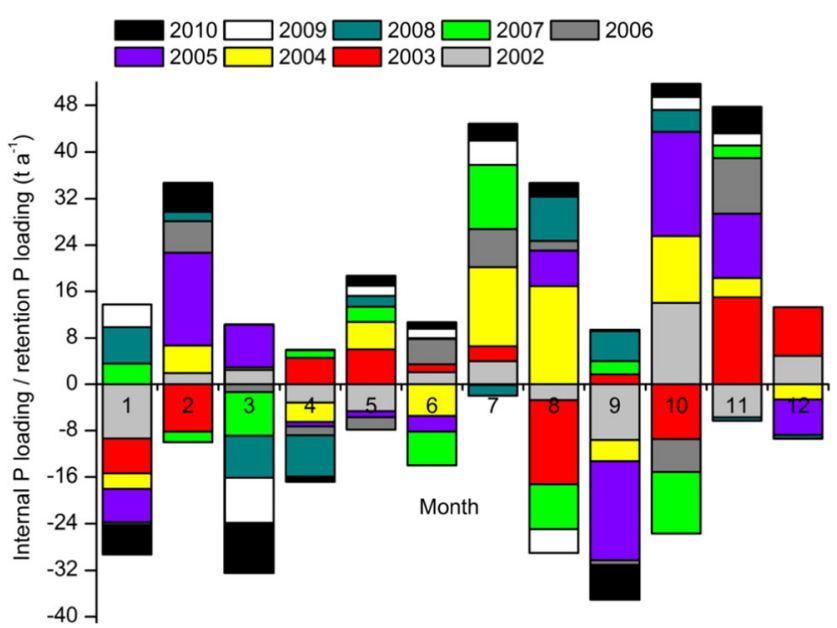

Fig. 5 The monthly internal $P$ loading (below the $X$ axis) and retention $P$ loading (above the $\mathrm{X}$ axis) from year 2002 to 2010

\section{Fick's law method}

$\mathrm{PO}_{4}-\mathrm{P}$ concentrations in the sediment porewater ranged from 0.002 to $0.027 \mathrm{mg} \mathrm{L}^{-1}$ in autumn, 0.001 to $0.36 \mathrm{mg} \mathrm{L}^{-1}$ in spring, and 0.007 to $0.416 \mathrm{mg} \mathrm{L}^{-1}$ in summer (Fig. 7). $\mathrm{PO}_{4}-\mathrm{P}$ in porewater changed significantly among seasons and sites (Kruskal-Wallis test, $P<0.01$ among seasons and $P<0.01$ between the eight sites of the three seasons). In July, the concentrations of $\mathrm{PO}_{4}-\mathrm{P}$ profiles varied greatly and maintained high concentrations compared with September and April at Kubei, Taoli, Baihedam, and Henghe. However, at Shuijiu, Jingou, and Chaohekuqu, $\mathrm{PO}_{4}-\mathrm{P}$ concentrations in April were higher. In contrast, the $\mathrm{PO}_{4}-\mathrm{P}$ profiles were relatively unchanged in September. Spatial variability in porewater of $\mathrm{PO}_{4}-\mathrm{P}$ also was observed within the sediment profiles; the $\mathrm{P}$ concentrations in the upper $10 \mathrm{~cm}$ were greater and more variable compared to those in deeper layers of the sediment.

Figure 8 shows the temporal variation of the $\mathrm{PO}_{4}-\mathrm{P}$ flux $\left(\mathrm{F}_{\mathrm{PO} 4}\right)$ between the sediments and the water column calculated by Eq. (6) of the three seasons from 2014 to
2015 (autumn, spring, and summer). Positive values of $\mathrm{PO}_{4}-\mathrm{P}$ flux indicate that sediment released $\mathrm{PO}_{4}-\mathrm{P}$ to the water column, whereas negative values indicate that the sediments retain $\mathrm{PO}_{4}-\mathrm{P}$ from the water column. In September 2014 (autumn), $\mathrm{F}_{\mathrm{PO} 4}$ was positive at all the sampling sites (sediment released $\mathrm{PO}_{4}-\mathrm{P}$ from the sediments to the water column), with values ranging from 0.034 to $0.203 \mathrm{mg} \mathrm{m}^{-2} \mathrm{~d}^{-1}$, and an average of $0.102 \mathrm{mg} \mathrm{m}^{-2} \mathrm{~d}^{-1}$. In April 2015 (spring), $\mathrm{F}_{\mathrm{PO} 4}$ values were all positive except at sites Kubei and Taoli, with values ranging from -0.099 to $1.064 \mathrm{mg} \mathrm{m}^{-2} \mathrm{~d}^{-1}$, and an average of $0.380 \mathrm{mg} \mathrm{m}^{-2} \mathrm{~d}^{-1}$. In July 2015 (summer), $\mathrm{F}$ PO4 values were positive in most of the sites except at sites Taoli and Henghe. The $\mathrm{F}_{\mathrm{PO} 4}$ values were ranged from -2.499 to $1.970 \mathrm{mg} \mathrm{m}^{-2} \mathrm{~d}^{-1}$, with an average of $0.030 \mathrm{mg} \mathrm{m}^{-2} \mathrm{~d}^{-1}$.

\section{Discussion}

\section{The implication from the union results of three methods}

Based on the results of the three methods to assess the internal P loading of the Miyun Reservoir, some useful information can be acquired. Sediment $P$ release rates are usually difficult to measure as they require time and resources, which are often not easy to be obtained. However, the regress method gave a new perspective to assess the internal $\mathrm{P}$ loading. Sediment $\mathrm{P}$ content was used to predict P release rate (Nürnberg 1988; Carter and Dzialowski 2012; Nürnberg and LaZerte 2016). For the whole reservoir, the release $\mathrm{P}$ rate was $0.889 \mathrm{mg} \mathrm{m}^{2}$ $\mathrm{d}^{-1}\left(25.53 \mathrm{t} \mathrm{y}^{-1}\right)$, which was about $17 \%$ of the external $\mathrm{P}$ loading. Nürnberg and LaZerte (2016) used this method in Lake Winnipeg and found that the internal $\mathrm{P}$ loading was about $7.2 \mathrm{mg} \mathrm{m}^{-2} \mathrm{~d}^{-1}\left(194 \mathrm{t} \mathrm{y}^{-1}\right)$, accounted $55 \%$ of the external P loading. Nürnberg et al. (2013) also obtained the
Table 1 The results of inflow, outflow retention and internal $\mathrm{P}$ loading

\begin{tabular}{lclll}
\hline Year & $\begin{array}{l}\text { Inflow P } \\
\text { loading }(\mathrm{t})\end{array}$ & $\begin{array}{l}\text { Outflow P } \\
\text { loading(t) }\end{array}$ & $\begin{array}{l}\text { Retention P } \\
\text { loading(t) }\end{array}$ & Internal P loading $(\mathrm{t})$ \\
\hline 2002 & 25.91 & 83.57 & 29.52 & 35.11 \\
2003 & 132.13 & 98.68 & 39.55 & 38.15 \\
2004 & 503.10 & 46.52 & 55.22 & 17.73 \\
2005 & 205.07 & 49.58 & 58.59 & 33.51 \\
2006 & 159.78 & 41.24 & 27.57 & 11.99 \\
2007 & 36.39 & 47.69 & 22.94 & 33.30 \\
2008 & 123.01 & 66.07 & 26.56 & 17.45 \\
2009 & 39.99 & 36.64 & 16.17 & 11.92 \\
2010 & 40.44 & 38.45 & 19.76 & 20.55 \\
Average & 140.65 & 56.49 & 32.88 & 24.41 (take up 17.35 \% of inflow P loading) \\
\hline
\end{tabular}


Fig. 6 Inflow P loading, outflow $\mathrm{P}$ loading, internal P loading, retention $\mathrm{P}$ loading (left axis) and mean annual precipitation (right axis)

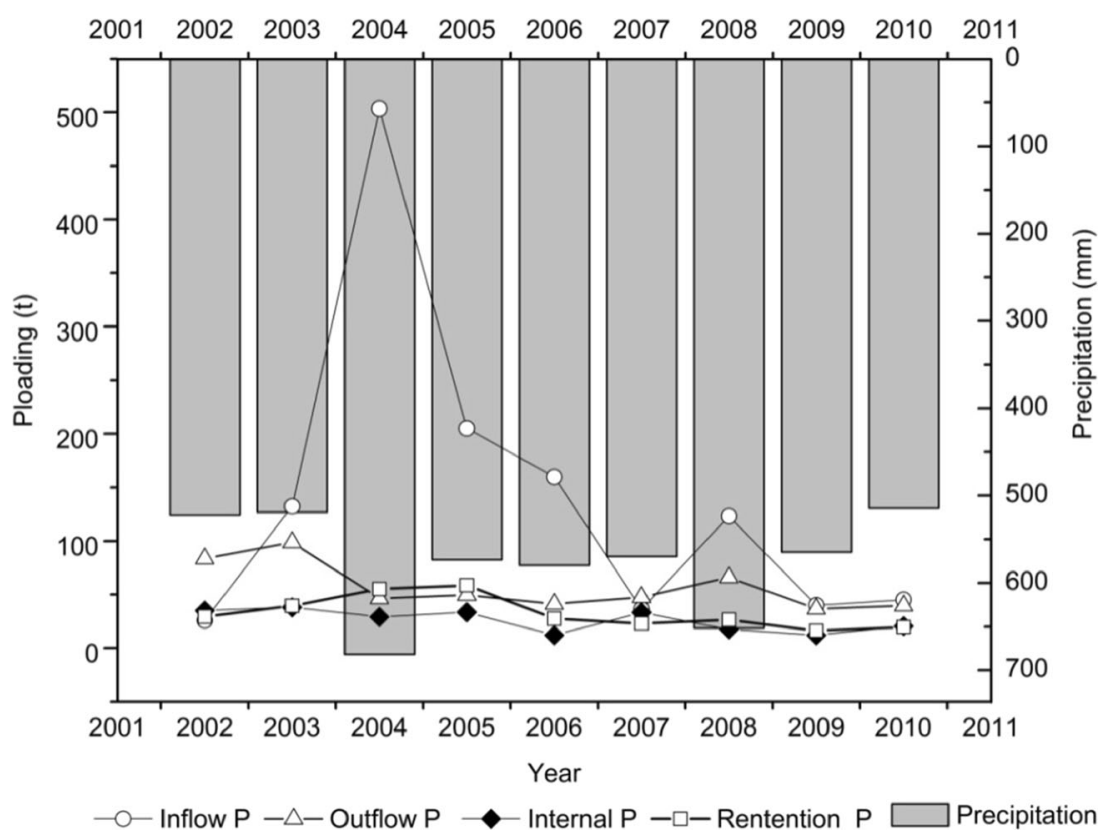

release $\mathrm{P}$ rate of Lake Simcoe, which was $0.236 \mathrm{mg} \mathrm{P}$ $\mathrm{m}^{-2} \mathrm{~d}^{-1}\left(62.9 \mathrm{t} \mathrm{y}^{-1}\right)$ correspondingly, taking up $89 \%$ of the external $\mathrm{P}$ load. The result showed that the region with higher TP concentration in the sediment contributes larger to the total internal loading. TP concentration in sediment appears to be an important factor in understanding the sediment-water interaction (Carey and Rydin 2011). Sediment P geochemistry can be an important index for estimating the $\mathrm{P}$ pool in pore water, and managing the flux of phosphorus (Mayer et al. 2006).
The analysis phosphate diffusion from sediment using Fick's first law were largely used (Malecki et al. 2004; Hansen and Márquez-Pacheco 2015; Yin and Kong 2015). Based on the theory of diffusion, diffusive gradients in thin films (DGT) is an in situ accurate measurement to determine the induced flux and concentration of elements in sediment (Han et al. 2015; Wu et al. 2015). In Taihu Lake, the DGT method showed that sediment can be both source and sink of $\mathrm{P}$ to the overlying water. In the contaminated region, the
Fig. 7 The distribution of $\mathrm{PO}_{4}{ }^{3}$ in sediment porewater

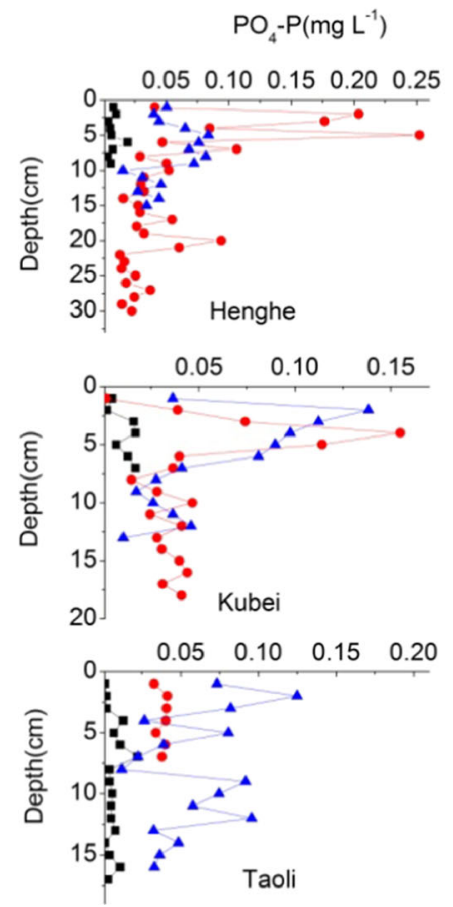

$\mathrm{PO}_{4}-\mathrm{P}\left(\mathrm{mg} \mathrm{L}^{-1}\right)$
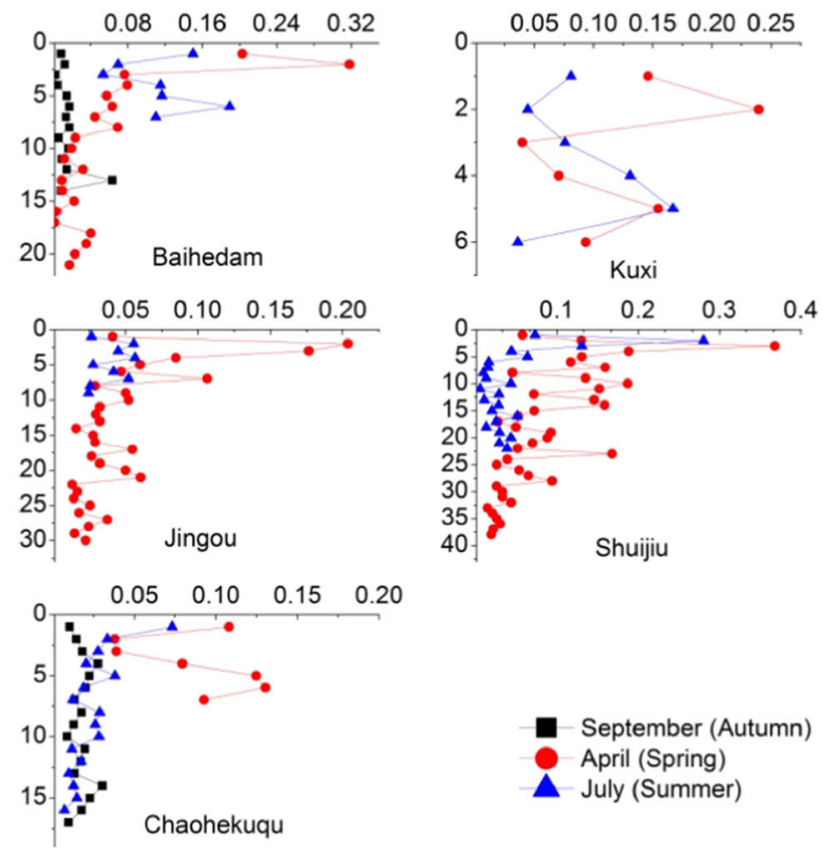

September (Autumn) April (Spring) July (Summer) 


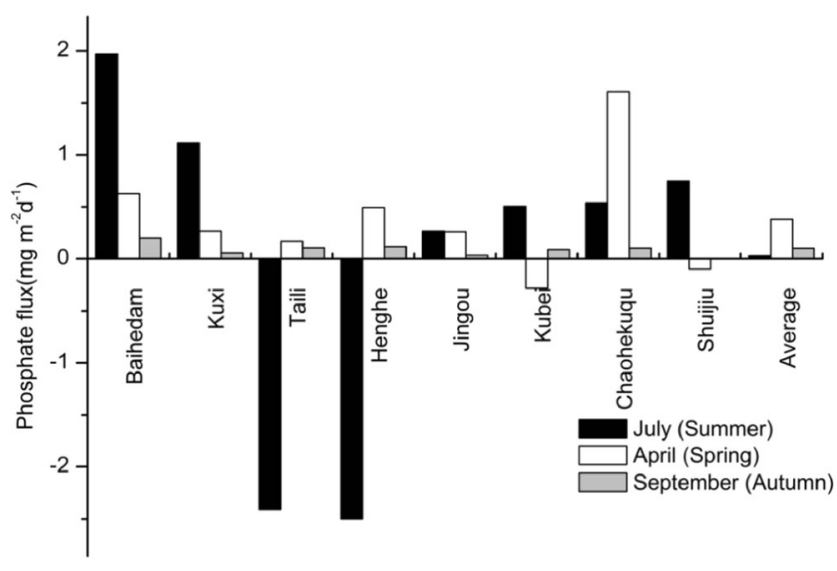

Fig. 8 Seasonal flux of phosphate

sediment tends to be source of $\mathrm{P}$, but in clear water region, it acts as sink of P (Ding et al. 2015). These were consistent with our results using traditional Fick's law method here (Fig. 8). Several other studies also support that phenomenon (Kisand and Nõges 2003; Chowdhury and Bakri 2006). The phosphate concentration in pore water reaches the peak at the top of the sediment, which was the same between these two methods (traditional Fick's law method or modified method-DGT) (Fig. 7). It can be attributed to the DO reduced as breakdown of the alga biomass and then triggers the release of $\mathrm{P}$ from the sediment (Cook et al. 2010; Wu et al. 2015). Internal P loading in stratified lakes during summer is complex and not easy to assess, as thermal stratification has effects on nutrient exchange between the hypolimnion and epilimnion. This may also be the reason why summer internal loading is less than spring and autumn (Soranno et al. 1997). Furthermore, just because internal $\mathrm{P}$ loading was more available for algal grow (Hickey and Gibbs 2009), so nuisance algal blooms should be taken care of in April and September, especially in Chaohekuqu and Baihedam (Fig. 8). From this aspect, Fick's law method was a good way to identify hot spot and period of internal $\mathrm{P}$ release.

The mass balance method (or P budget) is a highly useful tool for water quality management. It analyzes the complex-dynamic hydrological and biochemical systems (Waters and Webster-Brown 2016). In our study, the mass balance method analysis indicated that January, March to April (early spring), and August to September (late summer) were the time when $\mathrm{P}$ was most likely to be released. Hence, spring and summer are the most important periods to focus on water quality. In these seasons, internal $\mathrm{P}$ loading and temperature is suitable for phytoplankton growth; Microcystis is known to be affected by temperature and Oscillatoria is affected by total dissolved phosphorus ( $\mathrm{Su}$ et al. 2014). In late summer (August to September), algal blooms are likely to appear, consistent with the May to October bloom predictions of Zeng et al. (2015). Similarly, Nürnberg and LaZerte (2016) used mass balance method to calculate Lake Winnipeg, yielding internal $\mathrm{P}$ loading for the whole lake. The result revealed that internal $P$ loading occurred in the summer and fall during the study period. Waters and Webster-Brown (2016) used this method in Lake Forsyth and found that summer internal P loading was the dominant factor that affected the $\mathrm{P}$ concentration in the lake. As the mass balance method usually uses long-term monitoring data, so the trend of internal $\mathrm{P}$ loading across years was obvious.

Based on the three methods used in the study, the analysis can be enriched from different aspects. Compared with the other two methods, the parameters of regression method were easier to be obtained. The result usually showed in a general way of the whole lake or reservoir within a year (Greene et al. 2015). By using historical sediment $P$ concentration data or dating method with ${ }^{210} \mathrm{~Pb}$ or ${ }^{137} \mathrm{Cs}$, sediment core record can be traced back to the last century (Ruiz-Fernández et al. 2002; Xia et al. 2015), then, historical internal P release amount was calculated. It was generally based on annual output data. Fick's law method estimates the $\mathrm{P}$ flux using the concentration gradient between the sediment with overlying water (Yin and Kong 2015). The concentration gradient is almost instantaneous, such as daily P flux. Hot spot of internal P release was identified from this method (Fig. 8). Mass balance method with monthly or yearly data to calculate monthly or yearly retention or net release amount of the sediment (Nürnberg and LaZerte 2016; Waters and Webster-Brown 2016). Then, from monthly internal P loading/retention amount data, seasonal variation was obvious (Fig. 5). As a result, the three methods were different in the time scales of assessing internal $P$ release. These methods were given their focus on different aspects. By using them as a whole, a comprehensive understanding of internal $\mathrm{P}$ loading is possible.

\section{Comparison with other regions}

The mass balance method, regression method and Fick's law approaches were used in this study to estimate internal $\mathrm{P}$ loading. Compared to other regions, the release rate of SRP in Miyun Reservoir was low. Granéli (1999) reported that the $P$ flux ranged from 4.0 to $10.9 \mathrm{mg} \mathrm{m}^{-2} \mathrm{~d}^{-1}$ in Lake Ringsjön. Mayer et al.(2005) showed that the release rate of $\mathrm{P}$ was $0.27-4.43 \mathrm{mg} \mathrm{m}^{-2} \mathrm{~d}^{-1}$. The $\mathrm{P}$ release rates were almost 5-15-folds as in Miyun Reservoir of this study (Table 2). As shown by Rzepecki (2012), the release rate of DRP (dissolved reactive phosphorus) tended to be higher in eutrophic lakes than mesoeutrophic lakes. According to the surface water criterion (GB3838-2002), the Miyun Reservoir is a meso-eutrophic lake, which may account for lower P release rates. In addition, the morphometry of the water body, such as topography, water depth, and hydraulic retention time also affects internal P loading. For shallow water bodies, 
Table 2 Nutrient fluxes at sediment-water column interface from some other sites

\begin{tabular}{|c|c|c|c|c|}
\hline Site & Depth (m) & Methods & $\begin{array}{l}\mathrm{F} \\
\mathrm{mg} \mathrm{m}^{-2} \mathrm{~d}^{-1}\end{array}$ & $\begin{array}{l}\text { Sediment } \mathrm{P} \\
\text { content } \mu \mathrm{g} \mathrm{g}^{-1} \\
\mathrm{mg} \mathrm{kg}^{-1}\end{array}$ \\
\hline Cootes Paradise Marsh ${ }^{\mathrm{a}}$, & nd & Flux & $0.27-4.43$ & $891-1655$ \\
\hline Lake Ringsjön $^{\mathrm{b}}$ & 3.1 & $\mathrm{P}$ budget & $4.0-10.9$ & $1740-2320$ \\
\hline Mona Lake & 6.1 & Incubation & $\begin{array}{l}0.8-15.56 \\
(57.93 \%)\end{array}$ & $1500-5500$ \\
\hline Lake Okeechobee $^{\mathrm{d}}$ & 2.7 & Mass balance & $\begin{array}{l}1.9-5.6 \\
(11 \%)\end{array}$ & 1100 \\
\hline Miyun Reservoir ${ }^{\mathrm{e}}$ & 30 & Three methods & $\begin{array}{l}0.030-0.902 \\
(17.35 \%)\end{array}$ & $445-1026.2$ \\
\hline Lake Simcoe, Ontario $^{\mathrm{f}}$ & $14^{* *}$ & $\begin{array}{l}\text { Hypoxic factor and } \mathrm{P} \text { release } \\
\text { rates }\end{array}$ & $\begin{array}{l}4.3-8.8 \\
(45-89 \%)\end{array}$ & nd \\
\hline
\end{tabular}

${ }^{\text {a }}$ Mayer et al., 2005

${ }^{\mathrm{b}}$ Granéli, 1999

${ }^{\mathrm{c}}$ Steinman et al., 2009

${ }^{\mathrm{d}}$ Pollman and James, 2011

${ }^{\mathrm{e}}$ In this study

${ }^{\mathrm{f}}$ Nürnberg et al., 2013

*Average sampling site water depth

**Data from (Gudimov et al. 2012) nutrient exchange between sediment and water is affected by wind and bioturbation (Zhu et al. 2013). However, in deep lakes or reservoirs, wind may not be the main driving factor. Hence, the appropriate method to estimate internal P loading must reflect the physical condition of the water body. In the current case, sediment cores were not easy to obtain due to depth, and therefore, in situ analyses or core incubations were not logistically feasible.

Fluxes of $\mathrm{P}$ in the Miyun Reservoir or other palaces indicated bottom sediment was an important source of P. It takes up 11-89 \% of the external P loading (Table 1 and Table 2). Burger et al. (2007) also reported that the mean SRP sediment release rate was three times greater than daily external load. Therefore, internal P loading contributes to reservoirs (or lakes) loading significantly. In shallow lakes, internal $\mathrm{P}$ loading was widely regarded as a great source of nutrient (Welch and Cooke 1995; Nürnberg and LaZerte 2004; Steinman et al. 2009). However, internal nutrient released from sediment is often related to anoxia (Hupfer and Lewandowski 2008). There has been a number of reports confirmed that phosphorus release from bottom sediments was dominant by anoxic conditions (Andersen and Ring 1999, James and Barko 1991, Steinman et al. 2009, Welch and Cooke 1995). Consequently, in deep stratified water bodies, internal $\mathrm{P}$ loading should not be ignored. As demonstrated by Kowalczewska-Madura et al. (2015), P release from sediment varied between lakes of different trophic status. Seasonal variation is also a factor that influences $\mathrm{P}$ flux from sediment. Therefore, evaluating the internal P loading of the water bodies was very necessary and specific.

\section{The factors may affect internal P loading and water management}

The release of $\mathrm{P}$ from sediments is affected by several factors, such as oxygen condition (Selig 2003), bioturbation (Boström et al. 1988), temperature, and $\mathrm{pH}$ (Boers 1991; Wu et al. 2014). Besides those factors, sediment organic matter, iron and iron-to-P ratio, and particle size fractions also have been shown to influence sediment nutrient release. In addition, flushing rates can influence $P$ release. According to the law of conservation of mass, $\mathrm{P}$ entering lakes is either directly deposited in the sediment or flows out from the reservoir. The results showed that $P$ retention was positively related with inflow P load, in accordance with previous reports (Koiv et al. 2011). Parts of the retained $P$ would be buried as a permanently immobilized $\mathrm{P}$ fraction, whereas other parts would be mobile $\mathrm{P}$, susceptible to releasing $\mathrm{PO}_{4}{ }^{3-}$ to the overlying water. For Nürnberg and LaZerte (2004) revealed several stages about internal load changed with external load. External load triggers internal load and in turn internal load delays the recovery procedure from eutrophication stage.

Eutrophication has become the primary water quality issue for lake/pond/reservoir management. Human activities increased external loads, which have accelerated the eutrophication process and triggered internal nutrient loading processes (Reddy et al. 1998). As a result, internal loading can delay 
recovery of water quality even after the external nutrient load has decreased. Before taking actions to deal with eutrophication, much preliminary work needs to be done (Zamparas and Zacharias 2014), including monitoring all the potential nutrient sources (e.g., external nutrient loading and internal nutrient loading). Assessments of external nutrient loading have traditionally received more attention, such as with long-term monitoring programs or modeling efforts to assess different scenarios of external loads. Internal nutrient loading, in contrast, is influenced by many chemical, physical, and biological processes, and therefore may not be as easy to assess. In this study, three methods to assess internal P loading were compared with each other. To make eutrophication management decisions, a comprehensive assessment of nutrient contribution to the water body is needed. For a drinking water conservation area, such as Miyun Reservoir, much stricter basin water quality target management is proposed. To recovery from eutrophication, external nutrient reduction is essential, but internal load management may also be necessary.

\section{Conclusion}

Evaluating internal P loading is not easy, especially in large deep water bodies. It requires a great deal of time and effort. In this study, we used three different methods to assess the internal P loading in Miyun Reservoir, a deep water source reservoir in China. Regression method, Mass balance method, and Fick's law method resulted in different but complementary results. The regression method, which provides a general assessment based on sediment TP content, resulted in an estimated internal P load of $0.889 \mathrm{mg} \mathrm{m}^{2} \mathrm{~d}^{-1}$. The P mass balance method, which used 8 years of monthly data, calculated an average $P$ release rate of about $0.902 \mathrm{mg} \mathrm{m}^{2} \mathrm{~d}^{-1}$, with March to April and August to September being periods of special attention given the probability of algal blooms. Fick's law gave specific results about seasonal $P$ release rate at the monitoring stations. In April, Chahekuqu was the top site at about $1.60 \mathrm{mg} \mathrm{m}^{2} \mathrm{~d}^{-1}$, and in July, Baihedam had the highest $\mathrm{P}$ release rate at $1.97 \mathrm{mg} \mathrm{m}^{2} \mathrm{~d}^{-1}$. Our analysis revealed that for deep lakes or reservoirs, internal P loading should not be ignored. In the Miyun Reservoir, internal P loading was an important part for $\mathrm{P}$, accounting for about $17.35 \%$ of the total inflow P loading. Thus, for water eutrophication management, both external and internal P loading should be paid attention to. It also suggests that a more complete understanding of the internal P loading for reservoirs or lakes is merited.

Acknowledgments This research was funded by RCEES "One-ThreeFive" project (No. YSW2013B02-4) and the Major Science and Technology Program for Water Pollution Control and Treatment in China (No. 2014ZX07203010) and the Special Scientific Research of State Key Laboratory of Urban and Regional Ecology (NO. SKLURE2013-1-05). We would like thank Huimin Fu, Xiaoming
Yang, Qian Zhao, and Juan Chen for their supports during the sampling and experiment processes. We would also like to thank Dr. Pei Lei, Dr. Hongtao Zhao and Dr. Yan Jiang for their efforts on improving our manuscript.

\section{References}

Andersen FØ, Ring P (1999) Comparison of phosphorus release from littoral and profundal sediments in a shallow, eutrophic lake. Hydrobiologia 408:175-183. doi:10.1023/A:1017027818233

Anderson DM, Glibert PM, Burkholder JM (2002) Harmful algal blooms and eutrophication: nutrient sources, composition, and consequences. Estuaries 25(4):704-726. doi:10.1007/BF02804901

Benndorf J, Boing W, Koop J, Neubauer I (2002) Top-down control of phytoplankton: the role of time scale, lake depth and trophic state. Freshw Biol 47(12):2282-2295. doi:10.1046/j.1365-2427.2002. 00989.x

Bertrand NG, Marie SJ, Fidèle F, Jean-Marie DD (2015) Speciation of phosphorus in Lake Dang of Ngaoundere-Cameroon. Environ Sci Pollut Res 22(4):3098-3106. doi:10.1007/s11356-014-3586-0

Bhadha JH, Jawitz JW, Min J-H (2011) Phosphorus mass balance and internal load in an impacted subtropical isolated wetland. Water Air Soil Pollut 218(1):619-632. doi:10.1007/s11270-010-0673-9

Boers PCM (1991) The influence of $\mathrm{pH}$ on phosphate release from lake sediments. Water Res 25(3):309-311. doi:10.1016/0043-1354(91) 90010-N

Boström B, Andersen JM, Fleischer S, Jansson M (1988) Exchange of phosphorus across the sediment-water interface. Hydrobiologia 170(1):229-244. doi:10.1007/BF00024907

Burger DF, Hamilton DP, Pilditch CA, Gibbs MM (2007) Benthic nutrient fluxes in a eutrophic, polymictic lake. Hydrobiologia 584(1):1325. doi:10.1007/s10750-007-0582-0

Carter LD, Dzialowski AR (2012) Predicting sediment phosphorus release rates using landuse and water-quality data. Freshw Sci 31(4): 1214-1222. doi:10.1899/11-177.1

Carey CC, Rydin E (2011) Lake trophic status can be determined by the depth distribution of sediment phosphorus. Limnol Oceanogr 56(6): 2051-2063. doi:10.4319/1o.2011.56.6.2051

Chowdhury M, Bakri DA (2006) Diffusive nutrient flux at the sedimentwater interface in Suma Park reservoir, Australia. Hydrol Sci J 51(1):144-156. doi:10.1623/hysj.51.1.144

Conley DJ, Paerl HW, Howarth RW, Boesch DF, Seitzinger SP, Havens KE, Lancelot C, Likens GE (2009) Controlling eutrophication: nitrogen and phosphorus. Science 323(5917):1014-1015. doi:10. 1126/science. 1167755

Cook PLM, Holland DP, Longmore AR (2010) Effect of a flood event on the dynamics of phytoplankton and biogeochemistry in a large temperate Australian lagoon. Limnol Oceanogr 55(3):1123-1133. doi: 10.4319/lo.2010.55.3.1123

Cornwell JC, Glibert PM, Owens MS (2014) Nutrient fluxes from sediments in the San Francisco Bay Delta. Estuar Coasts 37(5):1120 1133. doi:10.1007/s12237-013-9755-4

Ding S, Han C, Wang Y, Yao L, Wang Y, Xu D, Sun Q, Williams PN, Zhang C (2015) In situ, high-resolution imaging of labile phosphorus in sediments of a large eutrophic lake. Water Res 74:100-109. doi:10.1016/j.watres.2015.02.008

Du X, Li X, Zhang W, Wang H (2014) Variations in source apportionments of nutrient load among seasons and hydrological years in a semi-arid watershed: GWLF model results. Environ Sci Pollut Res 21(10):6506-6515. doi:10.1007/s11356-014-2519-2

Graca B, Witek Z, Burska D, Białkowska I, Łukawska-Matuszewska K, Bolałek J (2006) Pore water phosphate and ammonia below the permanent halocline in the South-Eastern Baltic Sea and their 
benthic fluxes under anoxic conditions. J Mar Syst 63(3):141-154. doi:10.1016/j.jmarsys.2006.06.003

Granéli W (1999) Internal phosphorus loading in Lake Ringsjon. Hydrobiologia 404:19-26. doi:10.1023/a:1003705520085

Greene S, McElarney Y, Taylor D (2015) Water quality effects following establishment of the invasive Dreissena polymorpha (Pallas) in a shallow eutrophic lake: implications for pollution mitigation measures. Hydrobiologia 743(1):237-253. doi:10.1007/s10750-0142041-z

Gudimov A, O’Connor E, Dittrich M, Jarjanazi H, Palmer ME, Stainsby E, Winter JG, Young JD, Arhonditsis GB (2012) Continuous Bayesian network for studying the causal links between phosphorus loading and plankton patterns in Lake Simcoe, Ontario, Canada. Environ Sci Technol 46(13):7283-7292. doi:10.1021/es300983r

Haggard B, Moore P, DeLaune P (2005) Phosphorus flux from bottom sediments in Lake Eucha, Oklahoma. J Environ Qual 34(2):724 728. doi:10.2134/jeq2005.0724

Han C, Ding S, Yao L, Shen Q, Zhu C, Wang Y, Xu D (2015) Dynamics of phosphorus-iron-sulfur at the sediment-water interface influenced by algae blooms decomposition. J Hazard Mater 300:329337. doi:10.1016/j.jhazmat.2015.07.009

Hansen AM, Márquez-Pacheco H (2015) Internal phosphorus load in a Mexican reservoir: forecast and validation. Environ Toxicol Chem 34(11):2583-2589. doi:10.1002/etc.3102

Hickey CW, Gibbs MM (2009) Lake sediment phosphorus release management — decision support and risk assessment framework. N Z J Mar Freshw Res 43(3):819-856. doi:10.1080/00288330909510043

Hupfer M, Lewandowski J (2008) Oxygen controls the phosphorus release from lake sediments - a long-lasting paradigm in limnology. Int Rev Hydrobiol 93(4-5):415-432. doi:10.1002/iroh.200711054

James WF, Barko JW (1991) Littoral-pelagic phosphorus dynamics during nighttime convective circulation. Limnol Oceanogr 36(5):949960. doi:10.4319/lo.1991.36.5.0949

Jeppesen E et al. (2005) Lake responses to reduced nutrient loading —an analysis of contemporary long-term data from 35 case studies. Freshw Biol 50(10):1747-1771. doi:10.1111/j.1365-2427.2005. 01415.x

Jeppesen E, Søndergaard M, Meerhoff M, Lauridsen TL, Jensen JP (2007) Shallow lake restoration by nutrient loading reductionsome recent findings and challenges ahead. Hydrobiologia 584(1): 239-252. doi:10.1007/s10750-007-0596-7

Kelderman P, Wei Z, Maessen M (2005) Water and mass budgets for estimating phosphorus sediment-water exchange in Lake Taihu (China PR). Hydrobiologia 544(1):167-175. doi:10.1007/s10750005-0542-5

Kisand A, Nõges P (2003) Sediment phosphorus release in phytoplankton dominated versus macrophyte dominated shallow lakes: importance of oxygen conditions. Hydrobiologia 506(1):129-133. doi:10.1023/ B:HYDR.0000008620.87704.3b

Koiv T, Noges T, Laas A (2011) Phosphorus retention as a function of external loading, hydraulic turnover time, area and relative depth in 54 lakes and reservoirs. Hydrobiologia 660(1):105-115. doi:10. 1007/s10750-010-0411-8

Koriyama M, Hayami Y, Koga A, Yamamoto K, Isnasetyo A, Hamada T, Yoshino K, Katano T, Yamaguchi S (2013) Seasonal variations of water column nutrients in the inner area of Ariake Bay, Japan: the role of muddy sediments. Environ Monit Assess 185(8):6831-6846. doi:10.1007/s10661-013-3068-8

Kowalczewska-Madura K, Goldyn R, Dondajewska R (2010) The bottom sediments of Lake Uzarzewskie - a phosphorus source or sink? Oceanol Hydrobiol Stud 39(3):81-91. doi:10.2478/v10009-0100042-4

Kowalczewska-Madura K, Gołdyn R, Dera M (2015) Spatial and seasonal changes of phosphorus internal loading in two lakes with different trophy. Ecol Eng 74:187-195. doi:10.1016/j.ecoleng.2014.10.033
Lavery PS, Oldham CE, Ghisalberti M (2001) The use of Fick's first law for predicting porewater nutrient fluxes under diffusive conditions. Hydrol Process 15(13):2435-2451. doi:10.1002/hyp.297

Lehtoranta J, Ekholm P, Pitkänen H (2009) Coastal eutrophication thresholds: a matter of sediment microbial processes. Ambio 38(6):303308. doi:10.1579/09-A-656.1

Lewis GN, Auer MT, Xiang X, Penn MR (2007) Modeling phosphorus flux in the sediments of Onondaga Lake: insights on the timing of lake response and recovery. Ecol Model 209(2):121-135. doi:10. 1016/j.ecolmodel.2007.06.015

Li Z, Zhu D, Chen Y, Fang X, Liu Z, Ma W (2014) Simulating and understanding effects of water level fluctuations on thermal regimes in Miyun Reservoir. Hydrol Sci J. doi:10.1080/02626667.2014. 983517

Liu X (2002) The study of water eutrophication in Miyun Reservoir. Master Thesis, Capital Normal University

Malecki LM, White JR, Reddy K (2004) Nitrogen and phosphorus flux rates from sediment in the lower St. Johns River estuary. J Environ Qual 33(4):1545-1555. doi:10.2134/jeq2004.1545

Mayer T, Rosa F, Charlton M (2005) Effect of sediment geochemistry on the nutrient release rates in Cootes Paradise Marsh, Ontario, Canada. Aquat Ecosyst Health Manag 8(2):133-145. doi:10.1080/ 14634980590954986

Mayer T, Rosa F, Mayer R, Charlton M (2006) Relationship between the sediment geochemistry and phosphorus fluxes in a Great Lakes coastal marsh, Cootes Paradise, ON, Canada. Water Air Soil Pollut Focus 6(5):495-503. doi:10.1007/s11267-006-9033-6

Nürnberg GK (1985) Availability of phosphorus upwelling from iron-rich anoxic hypolimnia. Arch Hydrobiol 104(4):459-476

Nürnberg GK (1988) Prediction of phosphorus release rates from total and reductant-soluble phosphorus in anoxic lake sediments. Can J Fish Aquat Sci 45(3):453-462. doi:10.1139/f88-054

Nürnberg GK, LaZerte BD (2004) Modeling the effect of development on internal phosphorus load in nutrient-poor lakes. Water Resour Res 40(1):1-9. doi:10.1029/2003wr002410

Nürnberg GK (2009) Assessing internal phosphorus load - problems to be solved. Lake Reserv Manag 25(4):419-432. doi:10.1080/ 00357520903458848

Nürnberg GK, Tarvainen M, Ventelä A-M, Sarvala J (2012) Internal phosphorus load estimation during biomanipulation in a large polymictic and mesotrophic lake. Inland Waters 2(3):147-162. doi:10.5268/IW-2.3.469

Nürnberg GK, LaZerte BD, Loh PS, Molot LA (2013) Quantification of internal phosphorus load in large, partially polymictic and mesotrophic Lake Simcoe, Ontario. J Great Lakes Res 39(2):271-279. doi: 10.1016/j.jglr.2013.03.017

Nürnberg GK, LaZerte BD (2016) More than 20 years of estimated internal phosphorus loading in polymictic, eutrophic Lake Winnipeg, Manitoba. J Great Lakes Res 42(1):18-27. doi:10.1016/j.jglr.2015. 11.003

Nowlin WH, Evarts JL, Vanni MJ (2005) Release rates and potential fates of nitrogen and phosphorus from sediments in a eutrophic reservoir. Freshw Biol 50(2):301-322. doi:10.1111/j.1365-2427.2004.01316.x

Orihel DM, Hadas O, Pinkas R, Viner-Mozzini Y, Sukenik A (2013) A internal nutrient loading may increase microcystin concentrations in freshwater lakes by promoting growth of Microcystis populations. Ann De Limnol Int J Limnol 3:225-235. doi:10.1051/limn/2013052

Pedusaar T, Sammalkorpi I, Hautala A, Salujoe J, Jarvalt A, Pihlak M (2010) Shifts in water quality in a drinking water reservoir during and after the removal of cyprinids. Hydrobiologia 649(1):95-106. doi:10.1007/s10750-010-0231-x

Penn MR, Auer MT, Doerr SM, Driscoll CT, Brooks CM, Effler SW (2000) Seasonality in phosphorus release rates from the sediments of a hypereutrophic lake under a matrix of $\mathrm{pH}$ and redox conditions. Can J Fish Aquat Sci 57(5):1033-1041. doi:10.1139/cjfas-57-5-1033 
Pollman CD, James RT (2011) A simple model of internal loading of phosphorus in Lake Okeechobee. Lake Reserv Manag 27(1):15 27. doi:10.1080/07438141.2010.542877

Qin LH, Zeng QH, Li XY, Qin YM (2016) Distribution characteristics of organic matter and nutrient content in water-level-fluctuating zone of Miyun Reservoir inner lake. J Lake Sci (in Chinese). doi:10. $18307 / 2016.0401$

Reddy KR, Conner GAO, Gale PM (1998) Phosphorus sorption capacities of wetland soils and stream sediments impacted by dairy effluent. J Environ Qual 27(2):438-447. doi:10.2134/jeq1998. $00472425002700020027 \mathrm{x}$

Ruiz-Fernández A, Hillaire-Marcel C, Ghaleb B, Soto-Jiménez M, PáezOsuna F (2002) Recent sedimentary history of anthropogenic impacts on the Culiacan River Estuary, northwestern Mexico: geochemical evidence from organic matter and nutrients. Environ Pollut 118(3):365-377. doi:10.1016/S0269-7491(01)00287-1

Rzepecki M (2012) Dynamics of phosphorus in lacustrine sediments: the process of uptake/release of dissolved phosphorus by sediments in different habitats and lakes. Pol J Ecol 60(4):717-740

Søndergaard M, Jensen JP, Jeppesen E (2003) Role of sediment and internal loading of phosphorus in shallow lakes. Hydrobiologia 506(1):135-145. doi:10.1023/B:HYDR.0000008611.12704.dd

Søndergaard M, Bjerring R, Jeppesen E (2012) Persistent internal phosphorus loading during summer in shallow eutrophic lakes. Hydrobiologia 710(1):95-107. doi:10.1007/s10750-012-1091-3

Selig U (2003) Particle size-related phosphate binding and P-release at the sediment-water interface in a shallow German lake. Hydrobiologia 492(1):107-118. doi:10.1023/a:1024865828601

Smith L, Watzin MC, Druschel G (2011) Relating sediment phosphorus mobility to seasonal and diel redox fluctuations at the sedimentwater interface in a eutrophic freshwater lake. Limnol Oceanogr 56(6):2251-2264. doi:10.4319/1o.2011.56.6.2251

Soranno P, Carpenter S, Lathrop R (1997) Internal phosphorus loading in Lake Mendota: response to external loads and weather. Can J Fish Aquat Sci 54(8):1883-1893. doi:10.1139/cjfas-54-8-1883

Spears B, Carvalho L, Perkins R, Kirika A, Paterson D (2012) Long-term variation and regulation of internal phosphorus loading in Loch Leven. Hydrobiologia 681(1):23-33. doi:10. 1007/s10750-011-0921-z

Steinman A, Rediske R, Reddy KR (2004) The reduction of internal phosphorus loading using alum in Spring Lake, Michigan. J Environ Qual 33(6):2040-2048. doi:10.2134/jeq2004.2040

Steinman A, Chu X, Ogdahl M (2009) Spatial and temporal variability of internal and external phosphorus loads in Mona Lake, Michigan. Aquat Ecol 43(1):1-18. doi:10.1007/s10452-007-9147-6

Su M, Yu J, Pan S, An W, Yang M (2014) Spatial and temporal variations of two cyanobacteria in the mesotrophic Miyun reservoir, China. J Environ Sci 26(2):289-298. doi:10.1016/S1001-0742(13)60433-7
Waters S, Webster-Brown J (2016) The use of a mass balance phosphorus budget for informing nutrient management in shallow coastal lakes. J Hydro Environ Res 10:32-49. doi:10.1016/j.jher.2015.11.002

Welch EB, Cooke GD (1995) Internal phosphorus loading in shallow lakes: importance and control. Lake Reserv Manag 11(3):273-281. doi:10.1080/07438149509354208

Wu YH, Wen YJ, Zhou JX, Wu YY (2014) Phosphorus release from lake sediments: effects of $\mathrm{pH}$, temperature and dissolved oxygen. KSCE J Civ Eng 18(1):323-329. doi:10.1007/s12205-014-0192-0

Wu Z, Wang S, He M, Zhang L, Jiao L (2015) Element remobilization, "internal P-loading," and sediment-P reactivity researched by DGT (diffusive gradients in thin films) technique. Environ Sci Pollut Res 22(20):16173-16183. doi:10.1007/s11356-015-4736-8

Xia X, Wu Q, Zhu B, Zhao P, Zhang S, Yang L (2015) Analyzing the contribution of climate change to long-term variations in sediment nitrogen sources for reservoirs/lakes. Sci Total Environ 523:64-73. doi:10.1016/j.scitotenv.2015.03.140

Yang L, Lei K, Yan W, Li Y (2013) Internal loads of nutrients in Lake Chaohu of China: implications for lake eutrophication. Int J Environ Res 7(4):1021-1028

Yang M, Geng X, Grace J, Jia Y, Liu Y, Jiao S, Shi L, Lu C, Zhou Y, Lei G (2015) Responses of $\mathrm{N}_{2} \mathrm{O}$ flux to water level fluctuation and other environmental factors at littoral zone of Miyun reservoir: a comparison with $\mathrm{CH}_{4}$ fluxes. Biogeosci Discuss 12(7):5333-5363

Yin H, Kong M (2015) Reduction of sediment internal P-loading from eutrophic lakes using thermally modified calcium-rich attapulgitebased thin-layer cap. J Environ Manag 151:178-185. doi:10.1016/j. jenvman.2015.01.003

Zamparas M, Zacharias I (2014) Restoration of eutrophic freshwater by managing internal nutrient loads. A review. Sci Total Environ 496: 551-562. doi:10.1016/j.scitotenv.2014.07.076

Zeng Q, Qin L, Li X (2015) The potential impact of an inter-basin water transfer project on nutrients (nitrogen and phosphorous) and chlorophyll a of the receiving water system. Sci Total Environ 536:675686. doi:10.1016/j.scitotenv.2015.07.042

Zhang L, Wang L, Yin K, Lü Y, Zhang D, Yang Y, Huang X (2013) Pore water nutrient characteristics and the fluxes across the sediment in the Pearl River estuary and adjacent waters, China. Estuar Coast Shelf Sci 133:182-192. doi:10.1016/j.ecss.2013.08.028

Zhou Q, Gibson CE, Zhu Y (2001) Evaluation of phosphorus bioavailability in sediments of three contrasting lakes in China and the UK. Chemosphere 42(2):221-225. doi:10.1016/S0045-6535(00)00129-6

Zhu M, Zhu G, Li W, Zhang Y, Zhao L, Gu Z (2013) Estimation of the algal-available phosphorus pool in sediments of a large, shallow eutrophic lake (Taihu, China) using profiled SMT fractional analysis. Environ Pollut 173:216-223. doi:10.1016/j. envpol.2012.10.016 